\title{
POLA KUMAN AEROB PENYEBAB DIARE PADA ANAK BALITA DAN UJI KEPEKAAN ANTIBIOTIK DI BAGIAN ILMU KESEHATAN ANAK RSUP PROF. DR. R.D. KANDOU MANADO PERIODE MARET 2011-SEPTEMBER 2011
}

\author{
${ }^{1}$ Velma Buntuan \\ ${ }^{2}$ Sarah M. Warouw \\ ${ }^{1}$ Bagian Mikrobiologi Fakultas Kedokteran Universitas Sam Ratulangi Manado \\ ${ }^{2}$ Bagian Ilmu Kesehatan Anak Fakultas Kedokteran Universitas Sam Ratulangi Manado \\ Email:vbuntuan@gmail.com
}

\begin{abstract}
Diarrhoea is an increase of defecation frequency greater than usual (more than three times daily), associated with changes of the form and consistency of stools, soft or fluidy, and with or without mucus or blood. The causative agents of diarrhoea are e.g. Campylobacter, Salmonella, Shigella, dan Escherichia coli. Microbes' sensitivities against antibiotics can change from time to time, and from area to area. The purpose of this study was to find out the profile of aerobes that caused diarrhoea in childen under five admitted to the Children's Department, at the Prof Dr.R.D. Kandou General Hospital, as well as the sensitivity and resistency tests of microbes against antibiotics. Feces samples of the children were cultured, and microbial identifications and sensitivity tests against antibiotics were done. The causative microbes were Escherichia coli (40\%); and Klebsiella aerogenes, Klebsiella pneumonia, and Enterobacter aerogenes (each of them 3.3\%). Sensitivity tests against meropenem were $96.7 \%$ and against amikacin $90.0 \%$. Resistency tests to antibiotics showed sulpha methoxazole-trimethoprim 100\%, cefazolin 100\%, chloramphenicol $96.7 \%$, doxycicline $83.3 \%$, ampicillin $100 \%$, and ceftriaxon $60 \%$. Conclusion: the microbe that most caused diarrhoea in children under five admitted to the Children's Department of the Prof dr.R.D. Kandou General Hospital was Escherichia coli, and the most sensitive antibiotics against this microbe were meropenem and amikacin.
\end{abstract}

Key words: microbes' profile, diarrhoea, under five, sensitivity, antibiotics

\begin{abstract}
Abstrak: Diare adalah frekuensi buang air besar yang bertambah dari biasanya (lebih dari tiga kali), ditandai dengan perubahan bentuk dan konsistensi tinja yang lembek sampai cair, dengan atau tanpa darah atau lendir dalam tinja. Penyebab diare antara lain: Campylobacter, Salmonella, Shigella, dan Escherichia coli. Kepekaan kuman terhadap antibiotik dapat berbeda dari waktu ke waktu dan dari daerah ke daerah. Tujuan penelitian ini untuk mendapatkan pola kuman aerob penyebab diare pada balita, serta kepekaan dan resistensi kuman terhadap antibiotik. Feses balita yang rawat inap di Bagian Ilmu Kesehatan Anak RSUP Prof. Dr. R.D Kandou Manado dengan diare dibuat kultur, identifikasi kuman, dan uji kepekaan terhadap antibiotik. Kuman penyebab diare yaitu Escherichia coli (40\%), Klebsiella aerogenes, Klebsiella pneumonia, serta Enterobacter aerogenes (masing-masing 3,3\%). Kepekaan kuman terhadap antibiotik meropenem 96,7\% dan amikacin 90,0\%. Resistensi antibiotik diperoleh terhadap sulpha methoxazole trimethoprim sebesar $100 \%$, cefazolin $100 \%$, chloramphenicol $96,7 \%$, doxycicline $83,3 \%$, ampicillin $100 \%$, dan ceftriaxon $60 \%$. Simpulan: kuman penyebab diare terbanyak pada anak balita yang dirawat inap di Bagian Anak RSUP Prof Dr. R.D. Kandou Manado ialah Escherichia coli dan kepekaan antibiotik yang terbaik ialah meropenem dan amikasin.
\end{abstract}

Kata kunci: pola kuman, diare, balita, kepekaan, antibiotik 
Diare adalah frekuensi buang air besar yang bertambah dari biasanya (tiga kali atau lebih), ditandai dengan perubahan bentuk dan konsistensi tinja yang lembek sampai cair, dengan atau tanpa darah dan lendir dalam tinja. ${ }^{1-3}$ Bayi berusia lebih dari satu bulan dan anak-anak dinyatakan diare bila frekuensi buang air besar lebih dari tiga kali, sedangkan pada neonatus lebih dari empat kali dalam sehari. ${ }^{2,4}$

Etiologi diare dapat digolongkan dalam beberapa kelompok besar, yaitu: infeksi (bakteri, virus, atau parasit), malabsorbsi (kongenital atau didapat), keracunan bahan makanan tertentu, alergi, imunodefisiensi, terutama sIgA (secretory Immunoglobulin $A$ ), antibiotik, dan antasida yang mengandung magnesium.

Diagnosis diare ditegakkan berdasarkan gejala dan hasil pemeriksaan fisik. Penatalaksanaan penderita diare ialah pemberian cairan (rehidrasi) yang mengandung elektrolit dan glukosa atau karbohidrat lainnya untuk menggantikan cairan yang hilang, serta obat-obatan.,

Antibiotik merupakan suatu substansi kimia yang diperoleh dari atau dibentuk oleh berbagai spesies mikro-organisme yang dalam konsentrasi tertentu mampu menghambat pertumbuhan mikro-organisme lainnya. ${ }^{10}$

Uji kepekaan kuman dapat digunakan dengan dua cara: 1) cara cakram (disk difusion), 2) pengenceran antimikroba dalam agar (agar dilution). Cara difusi cakram paling banyak digunakan karena teknik pemeriksaannya lebih mudah. ${ }^{10}$ Interpretasi hasil uji kepekaan suatu mikroorganisme terhadap antibiotik berdasarkan pada hubungan minimal inhibitory concentration (MIC) atau minimal lethal concentration (MLC) pada organisme dengan konsentrasi antimikroba dalam darah atau urin dan feses. ${ }^{10}$

\section{ETIOLOGI DIARE PADA ANAK}

Terdapat beberapa etiologi penting yang sering ditemukan pada diare anak:

1. Infeksi bakteri (shigella, salmonella, E.coli, vibrio, Bacillus cereus, Clos- tridium perfingens, Staphylococcus aureus, campylobacter, aeromonas, dan yersinia enterocolitica); virus (rotavirus, adenovirus, Norwalk/Norwalk agent like virus, Enterovirus calicivirus); dan parasit (E. histolytica, Giardia lamblia, Balantidium coli, cryptosporadium, Balanitis humanis, ascaris, trichuris, strongyloides, candida). ${ }^{2,4,5}$

2. Malabsorbsi pada anak dengan imunokompeten dapat menyebabkan diare terutama setelah mengalami infeksi campylobacter, shigella, salmonella, giardia, cryptosporidium, coccidioidosis. Infeksi rotavirus lebih sering terjadi apada anak-anak yang mengalami malabsorbsi dengan immunocompromised. ${ }^{6}$ Baik malabsorbsi kongenital yang ditemukan terhadap sukrosa, isomaltosa, glukosa, atau galaktosa, serta defisiensi laktosa genetik, maupun malabsorbsi didapat dengan defisiensi laktosa dan sukrosa, serta intoleransi monosakarida dapat menyebabkan diare.

3. Keracunan bahan kimia yang dikandung dan diproduksi oleh jasad renik pada buah-buahan atau sayuran). ${ }^{3,4,6}$

4. Alergi terhadap makanan tertentu seperti susu sapi akan menyebabkan malabsorbsi karbohidrat, disakarida, lemak, protein, vitamin, dan mineral sehingga terjadi diare ${ }^{7}$.

5. Imunodefisiensi, terutama sIgA (Secretory Immunoglobulin A) yang mengakibatkan berlipat gandanya bakteri, flora usus, dan jamur terutama candida. Hal ini disebabkan karena sIgA sangat berperan dalam imunitas humoral lokal mukosa usus (local humoral mucosal immunity) dan mucosal cell mediated imunity (CMI). ${ }^{8}$

6. Penggunaan antibiotik dan antasida yang mengandung magnesium telah banyak dilaporkan dapat menyebabkan diare. ${ }^{9}$

\section{METODE PENELITIAN}

Penelitian ini merupakan penelitian laboratorik yang bersifat deskriptif prospek- 
tif. Lokasi penelitian untuk pengambilan sampel di Bagian Ilmu Kesehatan Anak RSUP Prof. Dr. R.D Kandou Manado selang bulan Maret sampai dengan September 2011. Identifikasi dan tes kepekaan terhadap antibiotik dilakukan di Laboratorium Mikrobiologi Layanan Terpadu Dinas Kehatan Provinsi Sulawesi Utara.

Populasi dan sampel terdiri dari pasien balita yang menderita diare di Bagian Ilmu kesehatan Anak RSUP Prof. Dr. R.D Kandou Manado yang rawat inap sebelum diberikan antibiotik atau sebelum pemberian antibiotik berikutnya.

Alat-alat yang digunakan yaitu lampu spiritus, sengkelit, gelas objek, cawan petri, lidi kapas steril, inkubator, mikroskop, tabung. Bahan-bahan yang digunakan ialah nutrient agar, MacConkey agar, garam fisiologis $(\mathrm{NaCl} 0,9 \%)$, zat pewarna Gram, media reaksi biokimia, media cair boulion. Disk antibiotik mengandung streptomisin $10 \mathrm{meg}$, tetrasiklin $10 \mathrm{meg}$, gentamisin 10 meg, kanamisin $30 \mathrm{meg}$, amoksisilin 25 meg, eritromisin 15 meg, oxytetrasiklin 30 meg, ciprofloksasin $30 \mathrm{meg}$, dan cephalexin $30 \mathrm{meg}$.

Variabel independen yang dipakai ialah pasien balita yang menderita diare, sedangkan variabel dependen ialah bakteri aerob dan uji resistensi antibiotik.

\section{HASIL DAN BAHASAN}

\section{Distribusi sampel berdasarkan jenis kelamin}

Sampel yang diperiksa sebanyak 30, dengan frekuensi terbanyak laki-laki 19 sampel (63\%) sedangkan perempuan 11 sampel (37\%). Hasil ini tidak sama dengan yang ditemukan di luar negeri dimana angka kesakitan lebih tinggi pada jenis kelamin perempuan sedangkan angka kematian lebih tinggi pada jenis kelamin laki-laki untuk semua usia. ${ }^{11}$ Hasil ini juga berbeda dengan penelitian Yusuf di Bagian Ilmu Kesehatan Anak Fakultas Kedokteran Universitas Syiah Banda Aceh dimana tidak terdapat perbedaan bermakna pada kedua jenis kelamin; untuk itu perlu dipelajari dan diteliti lebih lanjut. $^{12,13}$

\section{Distribusi sampel berdasarkan usia}

Dari hasil penelitian ditemukan bahwa anak yang mengalami diare terbanyak pada kelompok usia 0-2 tahun, dan paling sedikit pada usia 5 tahun. Hal ini sama dengan hasil penelitian dari Divisi Research and Science Analitico UI yang mengemukakan bahwa kasus diare sebagian besar terjadi pada anak berusia 1-4 tahun. ${ }^{13}$ Beberapa faktor yang mempengaruhi terjadinya diare pada anak, antara lain lingkungan, termasuk penyediaan air bersih dan jamban, pengetahuan, perilaku dan higene dari ibu, serta tingkat gizi anak. ${ }^{14}$

\section{Distribusi berdasarkan jenis bakteri}

Hasil kultur dan identifikasi menunjukkan bahwa kuman terbanyak yang tumbuh sebagai penyebab diare pada anak ialah Escherichia coli 12 sampel (40\%), Citrobacter difersus dan Providensia alkalifasiens masing-masing 6 sampel (20\%), dan Proteus vulgaris 3 sampel (10\%) sedangkan yang paling sedikit ialah Klebsiella aerogenes, Klebsiella pneumonia, dan Enterobacter aerogenes masingmasing 1 sampel $(3,3 \%)$. Hasil penelitian ini sama dengan yang dikemukakan Komalani dan Swajo, dimana Escherichia coli sebagai penyebab diare terbanyak. ${ }^{15}$

\section{Distribusi uji kepekaan antibiotik}

Penelitian ini menggunakan delapan jenis antibiotik. Kepekaan yang terbaik diperlihatkan oleh meropenem dan amikacin, masing-masing 29 sampel (96,7\%), sedangkan satu sampel $(3,3 \%)$ tergolong intermediate. Antibiotik yang telah resisten yaitu sulpha methoxazole trimethoprim 30 sampel (100\%), cefazolin 30 sampel (100\%), chloramphenicol 29 sampel $(96,7 \%)$ dan doxicycline 25 sampel $(83,3 \%)$, ampicillin 30 sampel (100\%), dan ceftriaxon 18 sampel $(60 \%)$.

Adanya resistensi yang tinggi dari beberapa jenis antibiotik tersebut di atas mungkin disebabkan oleh karena peng- 
gunaan antibiotik tersebut sangat bebas dan irasional. ${ }^{16}$ Sejak penisilin ditemukan dan mulai digunakan, jenis mikroba yang semula sensitif berkembang menjadi resisten terhadap antibiotik tersebut. Resitensi tersebut antara lain disebabkan oleh pembentukan enzim betalaktamase ekstrasel dalam jumlah relatif besar. ${ }^{16,17}$ Resistensi juga disebabkan oleh enzim autocilin yang tidak bekerja sehingga muncul sifat toleran bakteri terhadap antibiotik. ${ }^{16,17}$ Selain hal-hal di atas, bakteri tidak mempunyai dinding sel, sehingga perubahan penicillin binding protein (PBP) atau obat-obatan tidak mencapai reseptor PBP. ${ }^{16,17}$

Resistensi sel mikroba merupakan sifat dimana tidak terganggunya kehidupan sel mikroba oleh antimikroba. Sifat ini merupakan mekanisme alamiah untuk bertahan hidup. ${ }^{16,17}$ Faktor yang dapat menentukan sifat resistensi atau kepekaan mikroba terhadap anti-mikroba terdapat pada elemen yang bersifat genetik' dimana mikroba yang peka terhadap antimikroba dapat berubah sifat genetiknya menjadi tidak atau kurang peka. ${ }^{16,17}$

\section{SIMPULAN}

1. Pola kuman penyebab diare pada anak balita yang dirawat inap di Bagian Anak RSUP Prof Dr. R.D. Kandou Manado ialah terbanyak oleh Escherichia coli, kemudian disusul Citrobacter difersus, Providensia alkalifasiens, dan Proteus vulgaris. Klebsiella aerogenes, Klebsiella pneumonia dan Enterobacter aerogenes hanya dijumpai dalam jumlah kecil.

2. Usia penderita terbanyak 0-2 tahun.

3. Jenis kelamin laki-laki lebih sering ditemukan dari pada perempuan.

4. Antibiotik dengan kepekaan tertinggi ialah meropenem dan amikasin

\section{SARAN}

1. Kebersihan individu sangat penting untuk mencegah terjadinya diare.

2. Kultur feses penderita dengan diare perlu dilakukan untuk menegakkan diagnosis pasti dan penanganan yang tepat.

3. Perlu dilakukan tes kepekaan antibiotika untuk menghindari penggunaan antibiotik secara irasional, yang dapat memicu terjadinya resistensi kuman.

4. Perlu dilakukan penelitian lanjut dengan jumlah sampel yang lebih besar untuk mendapatkan informasi yang lebih akurat.

5. Perlu dilakukan pemetaan pola kuman pada pasien diare setiap enam bulan untuk mengetahui strain kuman penyebab diare.

\section{DAFTAR PUSTAKA}

1. Marlon BS, McMillan JA. In: Fine KS, editor. Blueprints Pediatrics (Third Edition). Massachussetts: Blackwell Publishing, 2004; p.82.

2. Staf Pengajar FKUI. Buku Kuliah Ilmu Kesehatan Anak 1. Jakarta: Bagian Ilmu Kesehatan Anak FKUI, 1985; hal.283-94.

3. Arijanty L. Diare pada anak. Dinkes [homepage on the Internet]. 2007 [cited 2011 March 12]; Available from: URL: http//www.medicastore.com.

4. Departeman Kesehatan RI Direktorat Jenderal Pemberantasan Penyakit Menular dan Penyehatan Lingkungan Pemukiman. Pedoman Pelaksanaan P2 Diare. Jakarta, 2000; hal.1-15.

5. Jawetz E, Melnick JL, Adelberg EA. Batang Gram-negatif enterik (Enterobactericeae). In: Elferia RN, Ramadhani D, Karolina S, Indriyani F, Rianti SSP, Yulia P, editors. Mikrobiologi Kedokteran (Edisi Keduapuluhtiga). Jakarta: EGC, 2007; hal.251-65.

6. Branski D, Shamir R. Intestinal infection and infestation associated with malabsorption. In: Kliegman RM, Stanton BF, St Geme III JW, Schor NF, Behrman RE, editors. Nelson Textbook of Pediatrics (Nineteenth Edition). Philadelphia: Elsevier Saunders, 2011; p.1313-4.

7. Lentze MJ, Branski D. Enzyme deficiencies. In: Kliegman RM, Stanton BF, St Geme III JW, Schor NF, 
Behrman RE, editors. Nelson Textbook of Pediatrics (Nineteenth Edition). Philadelphia: Elsevier Saunders, 2011; p.1317-8.

8. Seidman EG, Branski D. Immunodeficiency disorders. In: Kliegman RM, Stanton BF, St Geme III JW, Schor NF, Behrman RE, editors. Nelson Textbook of Pediatrics (Nineteenth Edition). Philadelphia: Elsevier Saunders, 2011; p.1314-5.

9. Sutardi, Maryani S. Diare. Bahan Kuliah Ilmu Kesehatan Anak Medan: FK USU, 2004; hal.102-7.

10. Nendrosuwito D. Standard Operating Procedures (SOP) in Microbiology. Jakarta: Departemen Kesehatan, 2000; hal.140-147.

11. Sutrisna B. Pengantar Epidemilogi. Jakarta: Dian Rakyat, 1994.

12. Yusuf S. Profile diare di ruang rawat inap anak. Bagian Ilmu Kesehatan Anak Fakultas Kedokteran Syiah/ Rumah Sakit Umum Daerah Dr. Zainoel Abidin, Banda Aceh [homepage on the Internet]. 2011 [cited 2011 June 20]. Available from: www.idai.or.id/ saripediatri/pdfile/13-4-6.pdf.

13. Divisi Research and Science Analitico UI. Kasus diare pada balita di Indonesia [homepage on the Internet]. 2000 [cited 2011 March 12]. Available from: www.analiticoui.blogspot.com/p/jurnaldan-artikel.html

14. Adisasmito W. Faktor resiko diare pada bayi dan balita di Indonesia. Makara Kesehatan [serial online]. 2007 [cited 2011 March 12];11(1):1-10. Available from: www.docstoc.com/docs 120665939

15. Komalarani S. Capaian Kesehatan Indonesia [homepage on the Internet]. Nodate [cited 2011 Jun 20]. Available from: http://elokdyah.multiply.com/ journal/itan/164

16. Kalalo LPA, Subagjo B. Pola bakteri dan tes kepekaan antibiotik wanita hamil dengan bakteriuria asimtomatik. Indonesian Journal of Clinical Pathology and Medical Laboratory [serial online]. Jul 2006 [cited 2011 Jun 20];12(3):103-109. Available from: journal.unair.ac.id

17. Istiantoro YH, Gan VHS. Penisillin, Sefalosporin dan antibiotik Betalaktam lainya. In: Gunawan SG, Setiabudy R, Nafrialdi, editors. Farmakologi dan Terapi (Edisi Kelima). Jakarta: Departemen Farmakologi dan Terapi FKUI, 2007; hal.664-71. 